\section{Tetsuo Shoji \\ Yoshiki Nishizawa \\ Takahiko Kawagishi \\ Masonori Emoto \\ Hirotoshi Morii}

Second Department of Internal Medicine,

Osaka City University Medical School,

Osaka, Japan

\title{
Secondary Hyperparathyroidism, Decreased Hepatic Triglyceride Lipase, Elevated Intermediate Density Lipoprotein and Atherosclerosis in Hemodialysis Patients
}

\section{Dear Sir,}

Cardiovascular mortality is higher in dialysis patients than the nonuremic population. This has been taken to indicate that dialysis patients have accelerated atherosclerosis [1]. We have recently revealed that atherosclerosis in hemodialysis patients is advanced morphologically, showing a greater intima media thickness in the carotid and femoral arteries in dialysis patients than healthy control subjects by high-resolution B mode ultrasonography [2]. Lipoprotein abnormality is one of the major risk factors for atherosclerosis in the general population, and recent studies [3-6] reemphasize the importance of triglyceride-rich lipoproteins such as partially lipolyzed very low density lipoprotein (VLDL) and intermediate density lipoprotein (IDL). These lipoprotein classes are significantly elevated in patients with chronic renal failure [7-9]. To under- stand the mechanism behind the increased IDL level in uremic patients, we examined factors responsible for the elevated IDL concentration in chronic renal failure patients.

The subjects were 24 hemodialysis patients, 42 peritoneal dialysis patients and 25 healthy controls. Their age and gender were comparable between the groups. Lipoproteins were measured by 1-step ultracentrifugation [8]. Lipoprotein lipase (LPL) and hepatic triglyceride lipase (HTGL) protein masses were measured in postheparin plasma by a sandwich enzyme immunoassay [10]. We previously reported elsewhere [8] that the IDL cholesterol level was markedly elevated in the hemodialysis $(13.6 \pm 1.4 \mathrm{mg} /$ $\mathrm{dl}$, mean $\pm \mathrm{SE}$ ) and peritoneal dialysis patients $(22.4 \pm 1.5 \mathrm{mg} / \mathrm{dl})$, as compared with the control level $(5.3 \pm 1.1 \mathrm{mg} / \mathrm{dl})$. LPL was not significantly different between the three groups, whereas HTGL was significantly lower in both hemodialysis $(557 \pm 96 \mathrm{ng} / \mathrm{ml})$ and peritoneal dialysis patients $(720 \pm$ $61 \mathrm{ng} / \mathrm{ml})$ than control subjects $(1,259 \pm$ $134 \mathrm{ng} / \mathrm{ml}$ ).

Table 1 summarizes the data by a univariate analysis of IDL cholesterol. VLDL cholesterol correlated positively to IDL cholesterol. LPL showed a weak positive relation with IDL cholesterol with a borderline significance. In contrast, HTGL was in a significant inverse relationship with IDL cholesterol. These univariate results are all consistent with the metabolic cascade of IDL; IDL is generated from VLDL via the action of LPL, and it is further metabolized by the action of HTGL. Then, we tried to find independent associations of the IDL cholesterol level with these factors by a multiple regression analysis (table 2). The results indicate
Table 1. Simple regression analysis of factors associated with IDL cholesterol

\begin{tabular}{lrr}
\hline Variable & $\mathrm{r}$ & $\mathrm{p}$ value \\
\hline VLDL cholesterol & 0.463 & 0.0001 \\
LPL & 0.208 & 0.0838 \\
HTGL & -0.291 & 0.0146
\end{tabular}

Simple regression analysis was performed to examine the correlation of IDL cholesterol with other variables in the 91 total subjects. $r=$ Correlation coefficient.
Table 2. Multiple regression analysis of factors determining IDL cholesterol level

\begin{tabular}{lrrl}
\hline Dependent variable & $\beta$ & $\mathrm{p}$ value & $\mathrm{R}^{2}$ \\
\hline VLDL cholesterol & 0.460 & 0.0001 & \\
LPL & 0.278 & 0.0001 & \\
HTGL & -0.334 & 0.0001 & $0.348(\mathrm{p}=0.0001)$
\end{tabular}

Factors determining IDL cholesterol were evaluated by multiple regression analysis in the 91 total subjects. $\beta=$ Standard partial regressin coefficient; $\mathrm{R}^{2}=$ multiple coefficient of determination.

\begin{tabular}{ll}
\hline KARGER & ( 1998 S. Karger AG, Basel \\
Fax +4161306 1234 34 2766/98/0781-0121\$15.00/0 \\
$\begin{array}{l}\text { E-Mail karger@karger.ch } \\
\text { www.karger.com }\end{array}$ & $\begin{array}{l}\text { This article is also accessible online at: } \\
\text { http://BioMedNet.com/karger }\end{array}$
\end{tabular}

Yoshiki Nishizawa, MD
Second Department of Internal Medicine
Osaka City University Medical School
1-5-7, Asahi-machi, Abeno-ku, Osaka 545 (Japan)
Tel. +81 66452111 , Fax +81 66452112 
that all of the VLDL cholesterol, LPL and HTGL levels significantly and independently related to the IDL cholesterol level.

These data provide clinical evidence that a decreased HTGL level is an important determinant of IDL accumulation in chronic renal failure. We previously reported that a decrease in HTGL was closely associated with a low ionized calcium concentration and elevated parathyroid hormone [8]. Therefore, we speculate that impaired calcium homeostasis and secondary hyperparathyroidism reduce the HTGL enzyme, increase the IDL level, and presumably accelerate atherogenesis in chronic renal failure. In support of this, the parathyroid hormone level was shown to be an independent risk factor of femoral atherosclerosis in hemodialysis patients [2]. To date, however, no published data are available that show the atherogenic role of IDL in patients with chronic renal failure. We are currently working to clarify this point.

\section{References}

1 Lindner A, Charra B, Sherrard DJ, Scribner $\mathrm{BH}$ : Accelerated atherosclerosis in prolonged maintenance hemodialysis. N Engl J Med 1974;290:697-701.

2 Kawagishi T, Nishizawa Y, Konishi T, Kawasaki K, Emoto M, Shoji T, Tabata T, Inoue T, Morii H: High-resolution B-mode ultrasonography in evaluation of atherosclerosis in uremia. Kidney Int 1995;48:820-826.

3 Krauss RM, Lindgren FT, Williams PT, et al: Intermediate-density lipoproteins and progression of coronary disease in hypercholesterolaemic men. Lancet 1987;ii:62-66.

4 Watts GF, Mandelia S, Bruns JNH, et al: Independent associations between plasma lipoprotein subfraction levels and the course of coronary artery disease in the St Thomas' Atherosclerosis Regression Study (STARS). Metabolism 1993;42:1461-1467.

5 Phillips NR, Waters D, Havel RJ: Plasma lipoproteins and progression of coronary artery disease evaluated by angiography and clinical events. Circulation 1993;88:2762-2770.
6 Mack WJ, Krauss RM, Hodis HN: Lipoprotein subclasses in the Monitored Atherosclerosis Regression Study (MARS). Treatment effects and relation to coronary angiographic progression. Arterioscler Thromb 1996;16:697-704.

7 Ron D, Oren I, Aviram M, Better OS, Brook JG: Accumulation of lipoprotein remnants in patients with chronic renal failure. Atherosclerosis 1983;46:67-75.

8 Shoji T, Nishizawa Y, Nishitani H, Yamakawa M, Morii H: Impaired metabolism of high density lipoprotein in uremic patients. Kidney Int 1992;41:1653-1661.

9 Nishizawa Y, Shoji T, Emoto M, Kawasaki K, Konishi T, Tabata T, Inoue T, Morii H: Reduction of intermediate density lipoprotein by pravastatin in hemo- and peritoneal dialysis patients. Clin Nephrol 1995;43:268-277.

10 Ikeda Y, Takagi A, Ohkaru K, Nogi T, Iwanaga S, Kurooka S, Yamamoto A: A sandwichenzyme immunoassay for the quantification of lipoprotein lipase and hepatic triglyceride lipase in human postheparin plasma using monoclonal antibodies to the corresponding enzymes. J Lipid Res 1990;31:1911-1924.

\section{Announcement}

\section{Charles E. Culpeper Foundation: New Grant Program}

The Charles E. Culpeper Foundation is pleased to announce the launching of a new grant program, the 'Biomedical Pilot Projects Initiative', designed to encourage investigation of new ideas in the areas of the Foundation's interest in health. The new initiative will provide awards of up to USD25,000 for a 1-year program to help foster the Foundation's interest, particularly in molecular genetics, bioengineering, molecular pharmacology, and health services.

The Charles E. Culpeper Foundation is a private, nonprofit charitable foundation established under the will of the late Charles E. Culpeper, one of the early pioneers in the bottling and marketing of Coca-Cola. In recent years, it has dispensed approximately USD 7 million/ year to activities in health, education, arts and culture, and the administration of justice.

Detailed information and application guidelines for the 'Biomedical Pilot Projects Initiative' are available on the World Wide Web at

www.culpeper.org

or from the

Charles E. Culpeper Foundation

Financial Centre

695 East Main Street

Stamford, CT 06901 (USA)

Tel. +1 (203) 9751240

$\mathrm{Fax}+1(203) 9751847$ 